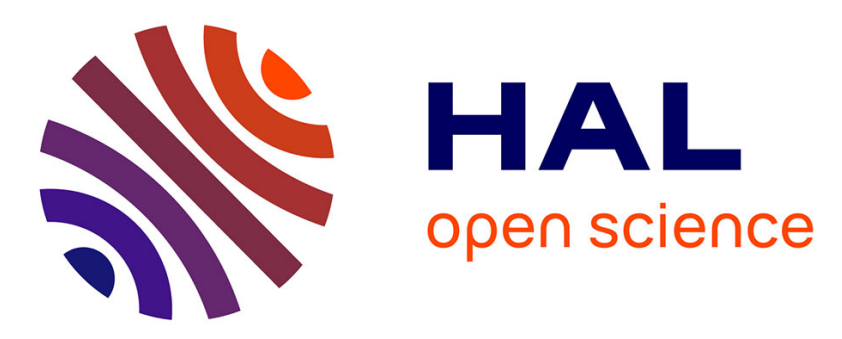

\title{
Assessing the flammability of surface fuels beneath ornamental vegetation in wildland-urban interfaces in Provence (South-Eastern France).
}

\author{
A. Ganteaume, M. Jappiot, C. Lampin
}

\section{- To cite this version:}

A. Ganteaume, M. Jappiot, C. Lampin. Assessing the flammability of surface fuels beneath ornamental vegetation in wildland-urban interfaces in Provence (South-Eastern France).. International Journal of Wildland Fire, 2012, 22 (3), p. 333 - p. 342. 10.1071/WF12006 . hal-00860792

\section{HAL Id: hal-00860792 https://hal.science/hal-00860792}

Submitted on 11 Sep 2013

HAL is a multi-disciplinary open access archive for the deposit and dissemination of scientific research documents, whether they are published or not. The documents may come from teaching and research institutions in France or abroad, or from public or private research centers.
L'archive ouverte pluridisciplinaire $\mathbf{H A L}$, est destinée au dépôt et à la diffusion de documents scientifiques de niveau recherche, publiés ou non, émanant des établissements d'enseignement et de recherche français ou étrangers, des laboratoires publics ou privés. 


\title{
Assessing the flammability of surface fuels beneath ornamental vegetation in wildland- urban interfaces in Provence (south-eastern France)
}

\author{
Anne Ganteaume ${ }^{\mathrm{A}, \mathrm{B}}$, Marielle Jappiot ${ }^{\mathrm{A}}$ and Corinne Lampin $^{\mathrm{A}}$ \\ A Irstea UR EMAX, 3275 route de Cézanne, CS 40061, F-13182 Aix-en-Provence, cedex 5, France. \\ ${ }^{\mathrm{B} C}$ Corresponding author. Email: anne.ganteaume@irstea.fr
}

\begin{abstract}
The objectives of this paper are to assess in laboratory conditions the flammability of undisturbed litter sampled beneath plants of seven species that are among those most frequently planted in hedges in Provence (southeastern France). Results were the variability in flammability recorded during burning experiments performed on undisturbed litter samples were partly explained by the proportions of the different litter components of each species. Phyllostachys sp. and Nerium oleander litters were the quickest to ignite whereas Prunus laurocerasus litter had the lowest bulk density and long time-to-ignition, but high flame-propagation. Photinia fraseri litter ignited frequently and had a high flame spread whereas Pittosporum tobira litter ignited the least frequently and for the shortest duration. Cupressus sempervirens litter had the highest bulk density and the longest flaming duration but the lowest flame propagation. Pyracantha coccinea litter was the slowest to ignite and flame propagation was low but lasted a long time. Co-inertia analysis identified species with the same flammability characteristics according to the composition of their litter. Hierarchical cluster analysis ranked the seven species in four distinct clusters from the most flammable (Photinia fraseri and Prunus laurocerasus) to the least flammable (Pittosporum tobira), the other species displaying two groups of intermediate flammability. The assessment of litter flammability of the seven species enabled them to be ranked in four clusters from poorly flammable (Pittosporum tobira) to highly flammable (Photinia fraseri and Prunus laurocerasus). These latter species should not be used in hedges planted in wildland-urban interfaces in south-eastern France.

The flammability of the undisturbed litter of seven species, among those most frequently planted in hedges in Provence (south-eastern France), was assessed in laboratory conditions. The flammability variables were partly explained by the proportions of the different litter components of each species. These species were ranked in four distinct clusters from the most flammable to the least flammable.
\end{abstract}

Additional keywords: flammability variables, hedge, litter composition, undisturbed litter

\section{Introduction}

In France, the south-east is the area the most affected by wildfires (55\% of the total number of fires in France for the period 2006-08 according to the French forest fire database Prométhée), mostly in the wildland-urban interface (WUI). These WUI fires are a serious threat to communities in many 
Author produced version of the article published in International Journal of Wildland Fire, 2012, 22(3) 333-342

Original publication available at www.publish.csiro.au/nid/114.htm

doi:10.171/WF12006

countries worldwide as highlighted in several reports (Leone et al. 2003; de la Riva and Perez-Cabello 2005; de la Riva et al. 2006; Jappiot et al. 2007).

In the WUI, homeowners are often advised to minimise or eliminate the use of highly flammable vegetation when landscaping their home, and lists containing species that are appropriate for use in fire-wise landscaping are often requested. Reducing the vegetation fire hazard can be accomplished through the arrangement, maintenance and selection of species. Studies have been carried out to identify native species with low flammability to be used in the WUI (Monroe et al. 2003).

Dimitrakopoulos (2001) and Etlinger and Beall (2004) provided an up-to-date review of vegetation flammability ratings in Europe and in the USA but without using a standard method to test and rank the flammability of plants. Indeed, few studies have compared the comprehensive flammability of many ornamental species.

The flammability, and especially the ignitability of live fuel used as ornamental plants has already been studied, mainly in the USA, using different methods (Babrauska 2003) including calorimetry (Etlinger and Beall 2004) at scales (White et al. 1997; Babrauskas 2002; Etlinger and Beall 2004) ranging from particles (Delabraze and Valette 1974 Dimitrakopoulos and Panov 2001; Dimitrakopoulos and Papaioannou 2001; Behm et al. 2004) to the whole plant (White et al. 1997; Babrauska 2002). In contrast, studies of the flammability of samples of dead surface-fuels originating from ornamental vegetation are very rare.

As reported by Etlinger and Beall (2004), the ignition of live vegetation could occur due to convection or radiation, but the ignition of dead surface-fuel (litter) often occurs from contact between burning or glowing brands and fuels mainly composed of non-woody particles (leaves) located near or under a plant. The importance of non-woody surface-fuel in wildfire has been addressed in numerous studies in terms of the effects of its arrangement (Bradstock and Cohn 2002) and morphology (Scarff and Westoby 2006), for instance. The flammability of the leaves or needles of the main Mediterranean species regarded as fuel or firebrand involved in spot fires has already been assessed in several studies (Valette 1990; Dimitrakopoulos and Papaioannou 2001; Ganteaume et al. 2009, 2011a, 2011b) but the flammability of litters sampled under vegetation planted in hedges remains to be assessed.

Flammability has been defined as having four components: ignitability, sustainability, combustibility and consumability (Anderson 1970; Martin et al. 1994).

Methods to assess and compare the flammability of litter and wildland fuels vary (Petriccione et al. 2006; Pellizzaro et al. 2007; Ormeño et al. 2009; Scarff and Westoby 2006); some use different burning devices such as fire benches (for dead fuels) and different types of ignition sources, usually calibrated samples of dead leaves of a given species (disturbed litter samples). The flammability of non-reconstructed litter samples, which are hypothesised to represent field conditions (as opposed to reconstructed litters that are typically studied (Jappiot et al. 2007)), has been studied in south-eastern 
Author produced version of the article published in International Journal of Wildland Fire, 2012, 22(3) 333-342

Original publication available at www.publish.csiro.au/nid/114.htm

doi:10.171/WF12006

France (Ganteaume et al. 2011a; Curt et al. 2011), but not in other Mediterranean countries.

Flammability also depends on the characteristics of the whole litter, in particular litter depth and bulk density (Pyne et al. 1996), and ventilation of the litter bed plays an important role in the burning process (Scarff and Westoby 2006). Regarding ornamental vegetation, Long et al. (2006a) provided flammability data for horticultural beds by evaluating the effect of the type of mulch, planting composition and drought conditions on fire spread and heat release in both field and controlledenvironment conditions. Several experiments were carried out on firebrands but very few used surface fuels (Manzello et al. 2006a, 2006b, 2007, 2008, 2009; Ganteaume et al. 2011b).

The present paper focuses on the flammability of dead surface-fuels collected under hedges, keeping intact the structure of the litter, i.e. litters that could be ignited by a spot fire. Indeed, in many WUI fires occurring in south-eastern France, the damage or losses is mainly caused by firebrands from nearby or distant fires that ignite the ornamental hedges usually planted to mark the boundary of the property around a house. In the present work, flammability was analysed bearing in mind the classical definition given by Anderson (1970), as the result of ignitability (time until ignition), combustibility (spread of the combustion after ignition) and sustainability (ability to sustain combustion once ignited). Therefore, litter flammability was assessed by means of its ignition frequency, time-toignition, flaming duration and flame spread across the sample.

\section{Material and methods}

\section{Study area and species studied}

The 'department' Bouches du Rhône is located in the eastern part of the Provence region (Fig. 1) and is among the areas most affected by wildfires in south-eastern France (54 fires and 1247.3 ha year $^{-1}$ burned in the 2000-10 period according to the regional forest fire database Prométhée). Because of the difference in climatic conditions between the coastal fringe and the inland part of the 'department' (Météo France database), this area was divided into two sub-study areas (coastal and inland) for sampling, as the species planted in the hedges may differ depending on their location. To identify the main species used, a survey of hedges was made in nine locations in both areas (117 hedges in four coastal locations and 110 hedges in five inland locations; Fig. 1). Among the 20 species recorded during this survey, assumed to be representative of the species planted in the whole study area, seven species were chosen for the study, either because of their frequency (e.g. Prunus laurocerasus (cherry laurel), Pyracantha coccinea (scarlet firethorn), Cupressus sempervirens (Italian cypress), Nerium oleander (oleander), Photinia fraseri (Christmas berry) and Pittosporum tobira (Pittosporum)) or because of their uniqueness (e.g. Phyllostachys sp. (bamboo), the only monocotyledon recorded, which may have unusual flammability characteristics). 
Author produced version of the article published in International Journal of Wildland Fire, 2012, 22(3) 333-342

列

doi:10.171/WF12006

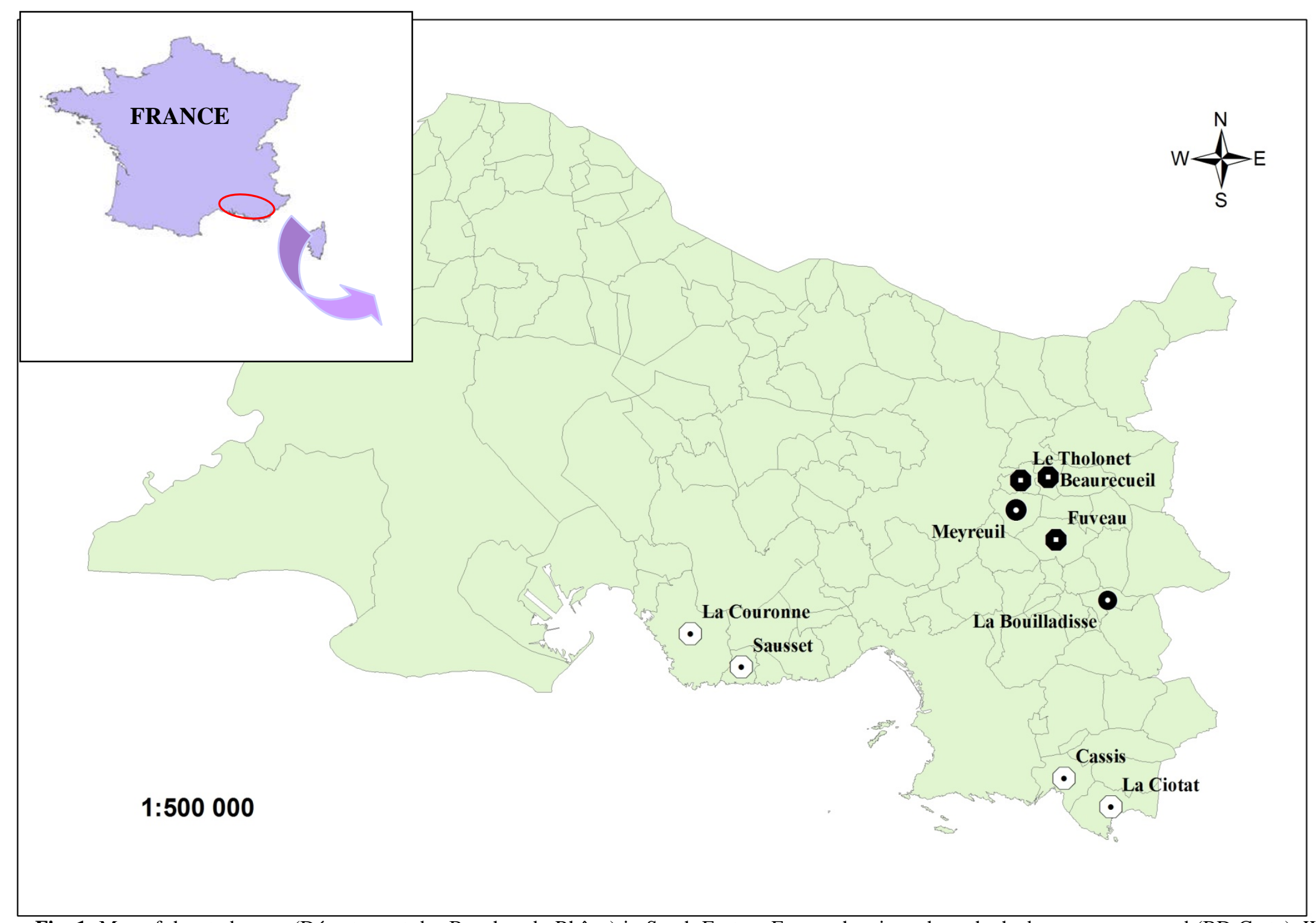

Fig. 1: Map of the study area (Département des Bouches du Rhône) in South-Eastern France showing where the hedges were surveyed (BD Carto). White spots: coastal area, black spots: inland area. 
Author produced version of the article published in International Journal of Wildland Fire, 2012, 22(3) 333-342

Original publication available at www.publish.csiro.au/nid/114.htm

doi:10.171/WF12006

\section{Field sampling}

Sampling was carried out during the fire season of July to August 2011. Undisturbed litter samples of each species were collected under the hedges, to take into account the real fuel structure, as a previous study highlighted the fact that the microstructure of the fuel affected the flammability of the litter (Ganteaume et al. 2011a). Thus, the litter samples were mainly composed of particles coming from the species studied but also from nearby species to a lesser extent. In the field, a metal template $(18 \times 20$ $\mathrm{cm}$ ) was used to delimit each litter sample, and a $20 \mathrm{~cm}$-wide trowel extracted the whole litter sample composed of the two main organic soil layers L and F, and of the upper part of layer H (Fig. 2). Each sample (whose size was the template's size: $18 \times 20 \mathrm{~cm}$ ) was numbered and directly placed in an aluminium tub (whose size was the same as the template) to prevent damage during transport to the laboratory. The samples were kept in these aluminium tubs from the time of sampling through the burning experiments. Before burning, the litter samples were oven dried for $48 \mathrm{~h}$ at $60^{\circ} \mathrm{C}$ to avoid any effect of fuel moisture content (FMC), which is known to be one of the most important factors influencing litter flammability and fire behaviour (Chuvieco et al. 2004).

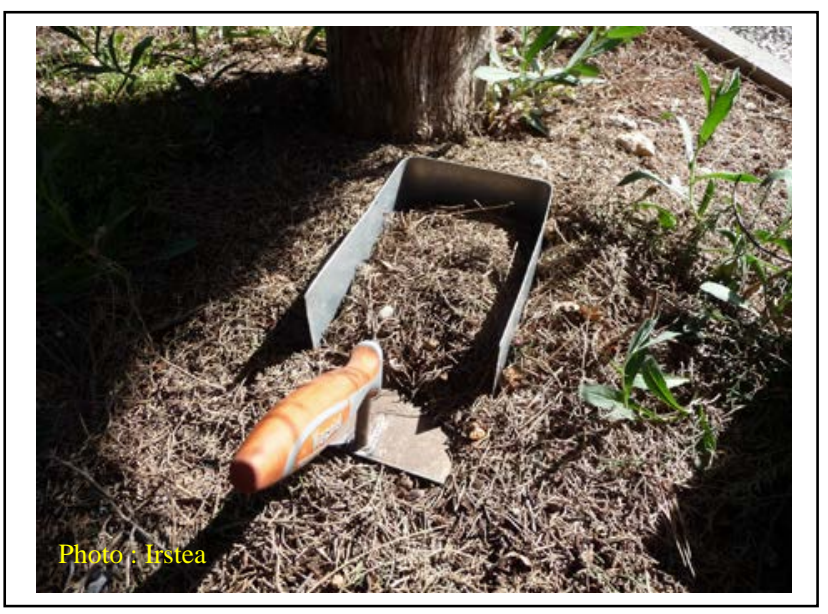

Fig. 2: Sampling of undisturbed cypress litter

\section{Description of the laboratory protocols \\ Sorting of litter samples}

A 50-g sub-sample of the oven-dried litter of each species was sorted in the laboratory to determine the proportions of the different litter components, as previous studies showed that litter composition affects flammability (Ganteaume et al. 2011a; Curt et al. 2011). For sorting, 10 classes of litter components were taken into account because of their specific flammability: (i) deciduous and (ii) evergreen leaves, (iii) scale-like leaves, (iv) needles, (v) fine particles ( $<2 \mathrm{~mm}$ in diameter) and (vi) coarse particles (>2 mm in diameter) mainly composed of twigs and fruits, (vii) grasses, (viii) non- 
Author produced version of the article published in International Journal of Wildland Fire, 2012, 22(3) 333-342

Original publication available at www.publish.csiro.au/nid/114.htm

doi:10.171/WF12006

combustible particles (stones, etc.), (ix) fine debris and (x) coarse debris (debris is defined here as unidentified plant material). For each sample, all the classes were weighed and their proportions were determined.

\section{Burning experiments using a fire bench}

The flammability experiments, performed at the Irstea Aix-en-Provence facility, were dedicated to the comparison of litter flammability, especially fire ignition and initial fire-propagation, between different species studied. To create conditions as close as possible to what occurs during a spot fire, when a glowing firebrand lands on the litter, we used the above-mentioned undisturbed litter samples (360 $\mathrm{cm}^{2}$ ) collected beneath the species studied, with replicates, and oven dried as described above. Each litter sample was placed on a fire bench made of cellular concrete to avoid overheating of the flammability device. In all experiments a domestic fan fixed onto a stand was used to direct a hot $\left(35^{\circ} \mathrm{C}\right)$, oblique $\left(45^{\circ}\right)$ and constant wind of $9.8 \pm 0.1 \mathrm{~km} \mathrm{~h}^{-1}$ across the surface of the samples (Fig. 3 ). To which extent this mimics the real direction of air flow in the field has not been tested. However, our measurements of the wind speed in the field indicated that a value of $\sim 9.8 \mathrm{~km} \mathrm{~h}^{-1}$ at the immediate vicinity of the soil surface can be considered as high. During the burning experiments, the longest side of the sample was positioned in the wind direction to weaken a possible bias due to its rectangular shape $(18 \times 20 \mathrm{~cm})$ although previous work has shown that shape has no significant effect on litter flammability (Jappiot et al. 2007).

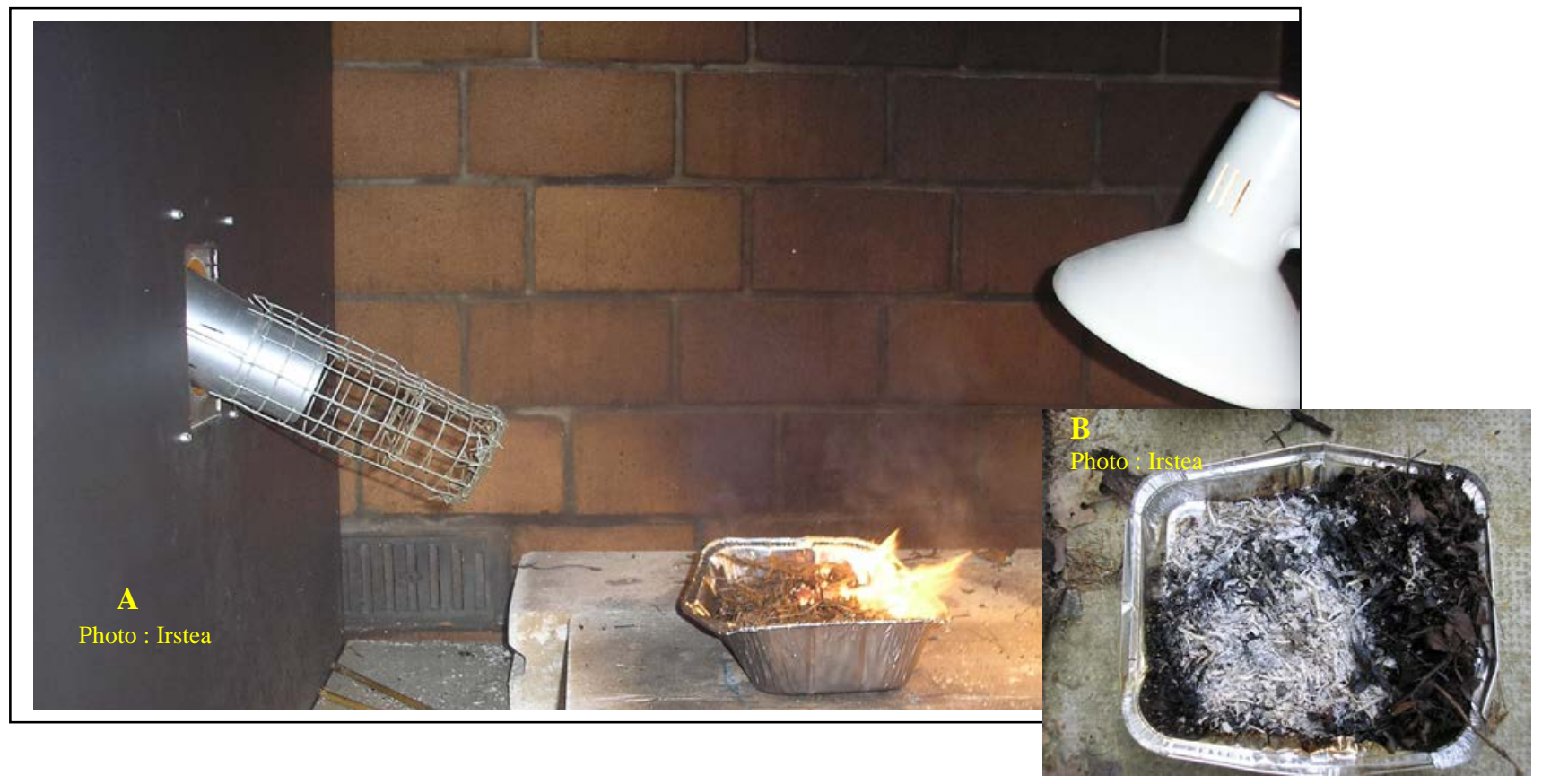

Fig. 3: The burning device used for the flammability experiments (A) and a top view of a burned sample showing the results of the flame spread (B). Domestic fan provides a $9.8 \mathrm{kmh}^{-1}$ wind. 
Author produced version of the article published in International Journal of Wildland Fire, 2012, 22(3) 333-342

Original publication available at www.publish.csiro.au/nid/114.htm

doi:10.171/WF12006

Air temperature and relative humidity were measured $\left(20.5^{\circ} \mathrm{C}\right.$ and $47.8 \%$ on average) throughout the experimental period (July to August 2010), but this did not affect flammability (Fisher's least significant difference (LSD) test, $P>0.05$ ). Before each ignition test, litter depth, biomass and bulk density were measured. The ignition setup was operated according to a protocol used in previous studies (Ganteaume et al. 2009, 2011a, 2011b), using a consistent Pinus sylvestris (Scots pine) deadwood piece $(2 \times 2 \times 1 \mathrm{~cm})$ that was left at room temperature to equilibrate to $\sim 7 \%$ moisture content. The wood piece was placed on a 500-W epiradiator at a constant temperature of $415^{\circ} \mathrm{C}$ and emitting a constant $7.5 \mathrm{~W} \mathrm{~cm}^{-2}$ radiation (Epiradiator Standard NF P 92-509-1985) until ignition, as described in Ganteaume et al. (2009). Once the flaming phase ended, the glowing 'firebrand' was placed in the centre of the sample and the timer was switched on. For each litter sample, up to three successive ignition trials were performed until the sample ignited. A variety of definitions of ignition success exist in the literature including the complete combustion of the sample (Frandsen 1997) or a minimum area burned (Lawson et al. 1996). In our study, ignition was considered successful if a flame lasted at least $10 \mathrm{~s}$ to ensure that ignition was sufficient to allow propagating flames (see Plucinski and Anderson 2008). The flammability parameters recorded in the experiments were the same as those taken into account in the work on spot fire of Ganteaume et al. (2009) because in the context of the WUI, fire very often propagates to the ornamental vegetation by spotting (ignition of the litter located beneath the hedge by a firebrand). Following the definitions of Anderson (1970), these variables were: (i) ignition frequency (IF, \%), which was computed as the number of successful ignitions relative to the number of trials for the same species; (ii) time-to-ignition (TTI, s), which corresponded to the time necessary for the appearance of a flame after the firebrand had been placed on the sample; (iii) number of different directions (0-4) of the sample reached by the flames and (iv) flaming duration (FD, s). The timer was stopped when flaming combustion finished.

\section{Statistical analyses}

The effect of species on the flammability variables was analysed using one-way analysis of variance (one-way ANOVA). In addition to the tests of overall significance with ANOVA, the Fisher's LSD test was used to check for significant differences between the variables. A significant relationship between the variables was assumed when $P \leq 0.05$. Some of the variables were previously log transformed to meet the one-way ANOVA assumption of normality and homoscedasticity. In all cases, when the distribution of data did not follow the expected parametric pattern or when a test condition involved insufficient data, a non-parametric Kruskal-Wallis test was used instead of a parametric Fisher test. These analyses were performed using Statgraphics Centurion XV.

Co-inertia analysis (Dolédec and Chessel 1994), suited to large numbers of variables compared with number of samples, was performed on the dependent variables (flammability and litter variables) and on the explanatory variables (proportions of the different components of the litter samples) to examine 
Author produced version of the article published in International Journal of Wildland Fire, 2012, 22(3) 333-342

Original publication available at www.publish.csiro.au/nid/114.htm

doi:10.171/WF12006

associations between litter composition and litter flammability. The complete data matrix was transferred to the statistical package under R v.2.5.1 (R Development Core Team 2005) then analysed using the ADE-4 package (Thioulouse et al. 1997). Co-inertia is a statistical method commonly used to analyse the relationship between species and environmental variables (e.g. Moretti and Legg 2009). The first step of the co-inertia analysis (ter Braak and Schaffers 2004) was to conduct a correspondence analysis (CA) on the litter's characteristics, then a principal component analysis (PCA) on the flammability variables. A factorial plane was thus created and enabled a new ordination of each dataset. The statistical significance of each effect or combination of effects was tested using a Monte-Carlo permutation test with 1000 permutations using the 'coin' package on R. High sums of eigen values on the main axes indicate high correlation among datasets.

Hierarchical cluster analysis (R software, ADE-4 package) of all the dependent variables (flammability variables) was used to group species into categories of flammability. The main aim of this analysis was to assign the different species into groups (clusters) in such a way that two species from the same cluster were more similar than two species from different clusters in terms of their flammability variables. Thus, species presenting the same type of flammability will be grouped in the same cluster, ranging from the less flammable species to the most flammable species.

\section{Results}

\section{Litter sorting}

Results of litter sorting are presented in Table 1. As the litter samples were collected undisturbed beneath hedges of each species studied, they were mainly composed of particles coming from the species studied but also from nearby species to a lesser extent. Thus, the proportions of deciduous leaves, needles, grass and non-combustible particles did not differ significantly among species (oneway ANOVA, $P>0.05$ ) and scale-like leaves and needles were not found in the litter of five of the seven species studied. However, the amounts of the other litter components were affected by the species: (i) evergreen leaves ( $F=126.26, P<0.0001)$ with maximum values recorded in $N$. oleander litter (69.64\%) and minimum in C. sempervirens litter (0.01\%), (ii) fine particles ( $F=2.66, P=0.033$ ) with maximum values recorded in P. coccinea litter (10.02\%) and minimum in Phyllostachys sp. litter (3.01\%), (iii) coarse particles ( $F=9.05, P<0.0001)$ with maximum values in $C$. sempervirens litter (21.94\%) but absent from $P$. fraseri litter, (iv) fine debris $(F=10.26, P<0.0001)$ and (v) coarse debris $(F=7.56, P=0.0001)$. The highest fine-and coarse-debris values were recorded in Phyllostachys sp. litter (32.82 and 43\%) and the lowest in N. oleander litter (0.41 and 1.69\%). The proportion of scale-like leaves varied significantly between C. sempervirens litter (20.73\%) and that of $P$. coccinea $(0.12 \%)(F=60.95, P=0.0015)$ and this component was not found in the litter of the other species. For each component, the proportions of the different components that differed significantly between species are given in Fig. 4. 
Author produced version of the article published in International Journal of Wildland Fire, 2012, 22(3) 333-342 Original publication available at www.publish.csiro.au/nid/114.htm doi:10.171/WF12006

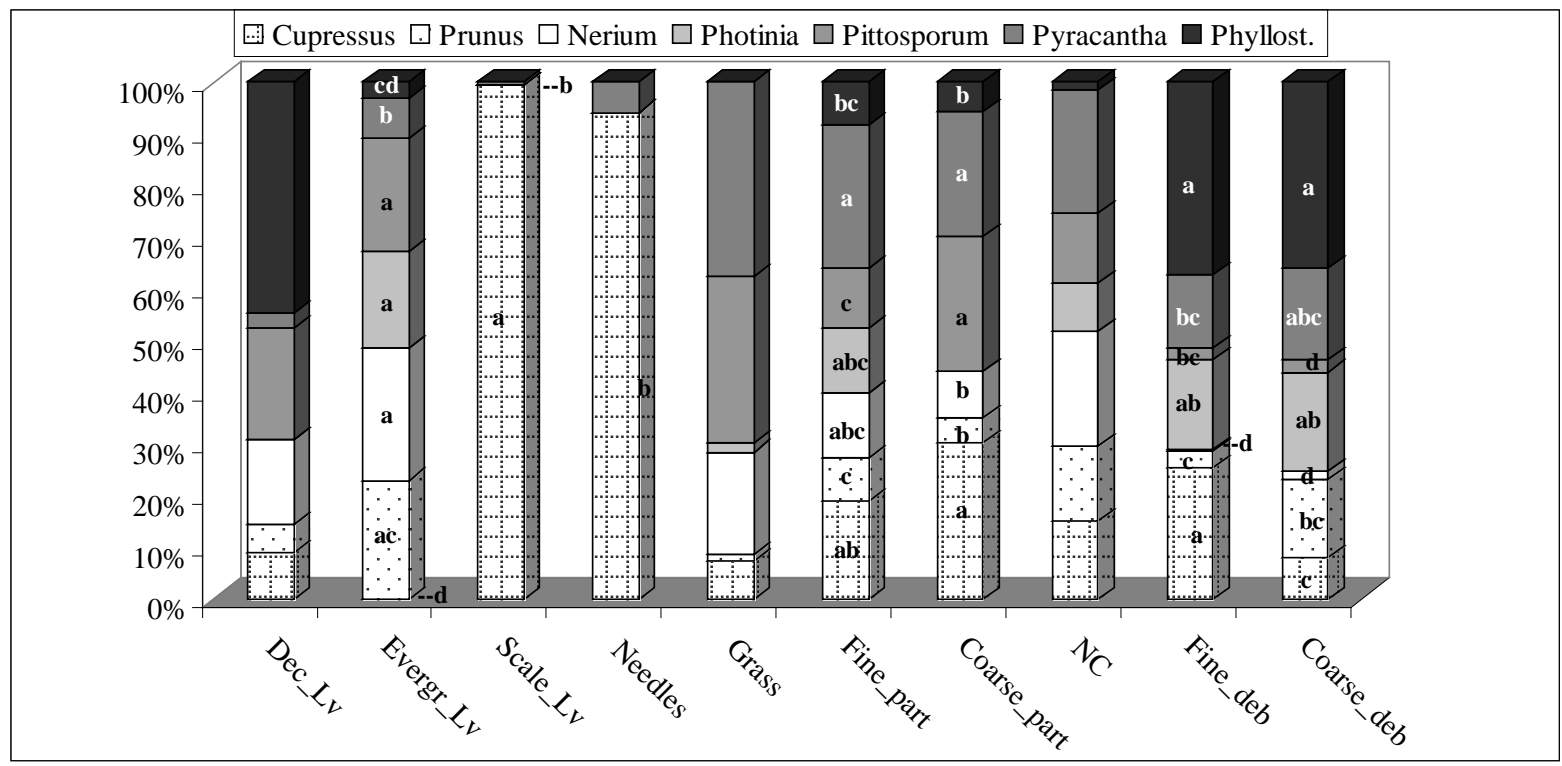

Fig. 4: Litter composition (percent of each component) of each species studied (Phyllost.: Phyllostachys sp.;

Dec_Lv: deciduous leaves; Evergr_Lv: evergreen leaves, scale_lv: scale-like leaves; N: needles, Gr: grass; fine_part: fine particles, coarse_part: coarse particles; NC: non-combustible; fine_deb: fine debris; coarse_deb: coarse debris). For each bar, different letters indicate a statistically significant difference among species according to the one-way ANOVA. Where no letters are indicated, no differences among species were detected (proportions of each component were log-transformed).

\section{Flammability experiments on the fire bench}

Results of the flammability experiments are presented in Table 2. Photinia fraseri, C. sempervirens and $P$. coccinea litters ignited very frequently (IF $\geq 90 \%$ ) in contrast to $P$. tobira and $N$. oleander litters (20 and 57\%). Litters sampled in hedges of $N$. oleander and Phyllostachys sp. were the quickest to ignite (49 and $56 \mathrm{~s}$ ) in contrast to P. laurocerasus and P. coccinea litters (153 and 188 s). The longest flaming durations were recorded in C. sempervirens and P. coccinea litters (148 and $145 \mathrm{~s}$ ) and the shortest in P. tobira litter (55 s). The best flame spread was recorded in P. fraseri litter (all four sides of the sample were reached by the flames) unlike $C$. sempervirens litter in which on average only two sides of the sample were reached by the flames. The lowest litter bulk density was recorded in P. laurocerasus litter $\left(27 \mathrm{~kg} \mathrm{~m}^{-3}\right)$ and the highest in C. sempervirens litter $\left(243 \mathrm{~kg} \mathrm{~m}^{-3}\right)$.

The one-way ANOVAs revealed that the 'species' factor very significantly affected litter flammability variables and litter bulk density (Table 2) but there was no correlation between flaming duration and bulk density. With respect to ignitability, the ignition frequency of $P$. tobira litter was significantly lower than that of the other species. The time-to-ignition of $N$. oleander litter was 
Author produced version of the article published in International Journal of Wildland Fire, 2012, 22(3) 333-342 Original publication available at www.publish.csiro.au/nid/114.htm doi:10.171/WF12006

significantly shorter than that of the others species except Phyllostachys sp. For P. coccinea litter, this variable was significantly higher than for the other species, except $P$. laurocerasus (Fig. 5a). With respect to sustainability, the flaming duration of $P$. fraseri, $P$. coccinea and $C$. sempervirens litters was significantly longer, and that of $P$. tobira litter significantly shorter, than that of the other species (Fig. $5 b$ ). With respect to combustibility, the flame spread in $P$. fraseri litter was significantly higher whereas that in $C$. sempervirens and $P$. coccinea litters was significantly lower than that in the other species except P. tobira (Fig. 5c).

A. Means plot and Fisher's LSD intervals

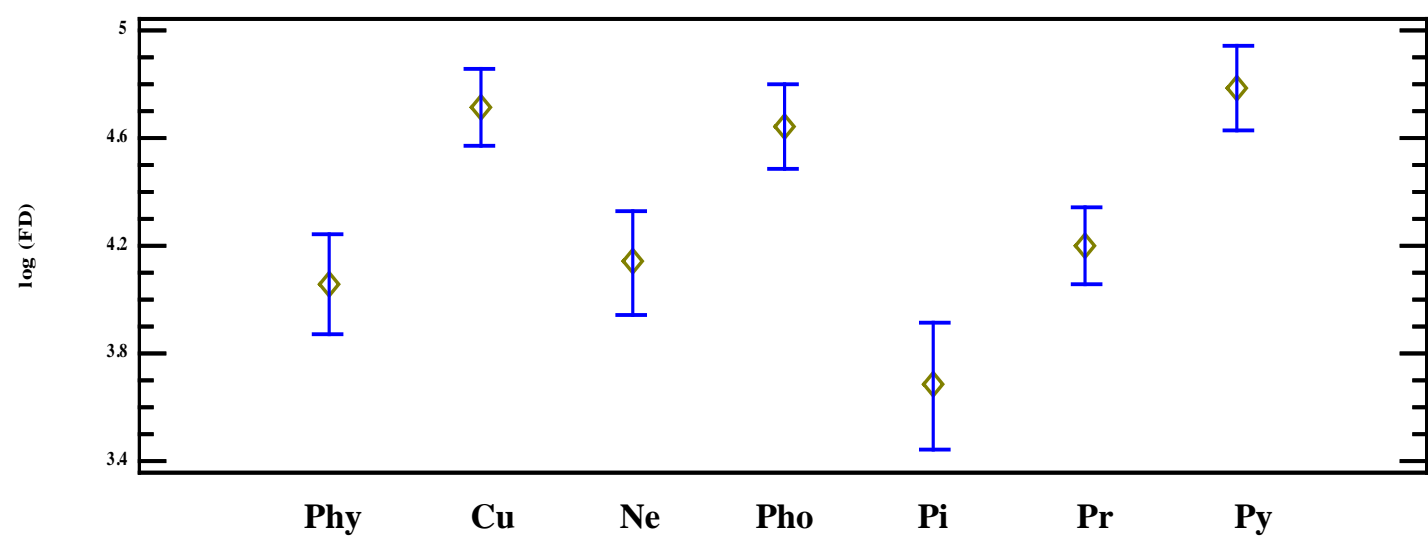

B.

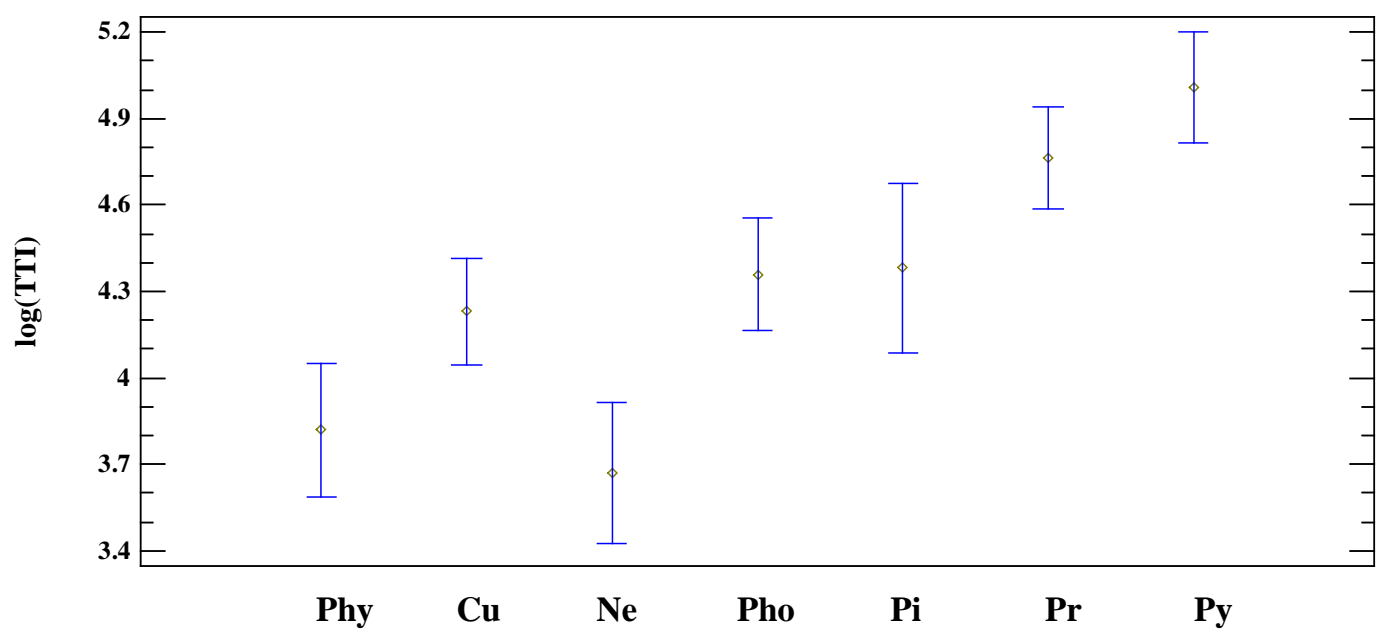


C

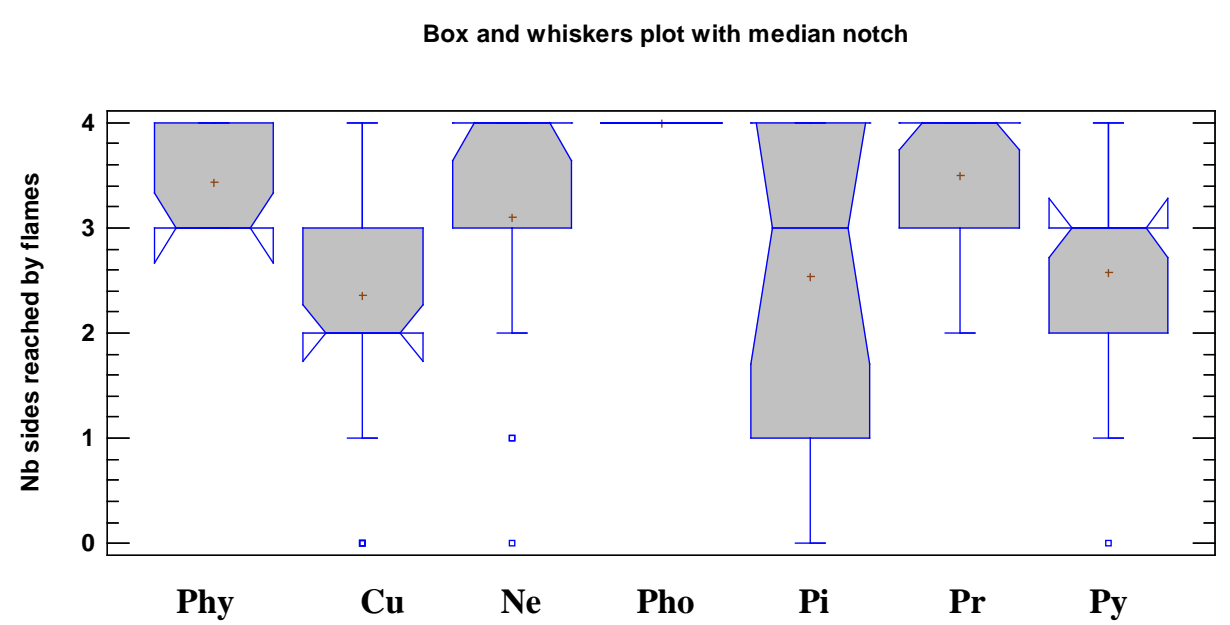

Fig. 5: Variations in (A) time-to-ignition (TTI), (B) flaming duration (FD) and (C) flame spread (Nb of sides reached by the flames) of the litter samples as a function of the species (Phy: Phyllostachys, Cu: Cupressus, Ne: Nerium, Pho: Photinia, Pi: Pittosporum, Pr: Prunus, Py: Pyracantha). one-way ANOVAs: Box extends from lower quartile to upper quartile covering $50 \%$ of the data values. Horizontal line within the box shows the location of the sample median and plus sign shows the location of the sample mean. Whiskers extend from the quartile to the largest or smallest value in the sample. Notch covers an approximate confidence interval for the population median (confidence level=95\%).

\section{Classification of species}

The cloud plot extracted from the co-inertia analysis (Fig. 6) showed the position of the dependent variables (flammability and litter variables) and of the explanatory variables (litter components). The first axis explained $68.65 \%$ of variance and differentiated litters with high bulk density and flaming duration values (C. sempervirens and $P$. coccinea) from those whose values for these variables were low. The second axis explained $19.05 \%$ of variance and differentiated litters with high ignition frequency, flame spread values or both and low time-to-ignition values (P. fraseri, Phyllostachys sp. and $P$. laurocerasus) from litters with low ignitability (long time-to-ignition, low ignition frequency or both) or low flame spread values (P. tobira and N. oleander). High bulk density was linked to the large amount of scale-like leaves that characterised $C$. sempervirens litter, and long flaming duration was linked to the high amounts of fine and coarse particles that characterised $C$. sempervirens and $P$. coccinea litters. High ignition frequency and high flame spread were linked to the large amounts of debris that characterised Phyllostachys sp., P. fraseri and P. laurocerasus litters. Long time-to-ignition 
Author produced version of the article published in International Journal of Wildland Fire, 2012, 22(3) 333-342 Original publication available at www.publish.csiro.au/nid/114.htm doi:10.171/WF12006

was linked to the high amounts of coarse and non-combustible particles that characterised $P$. tobira and $P$. coccinea litters.

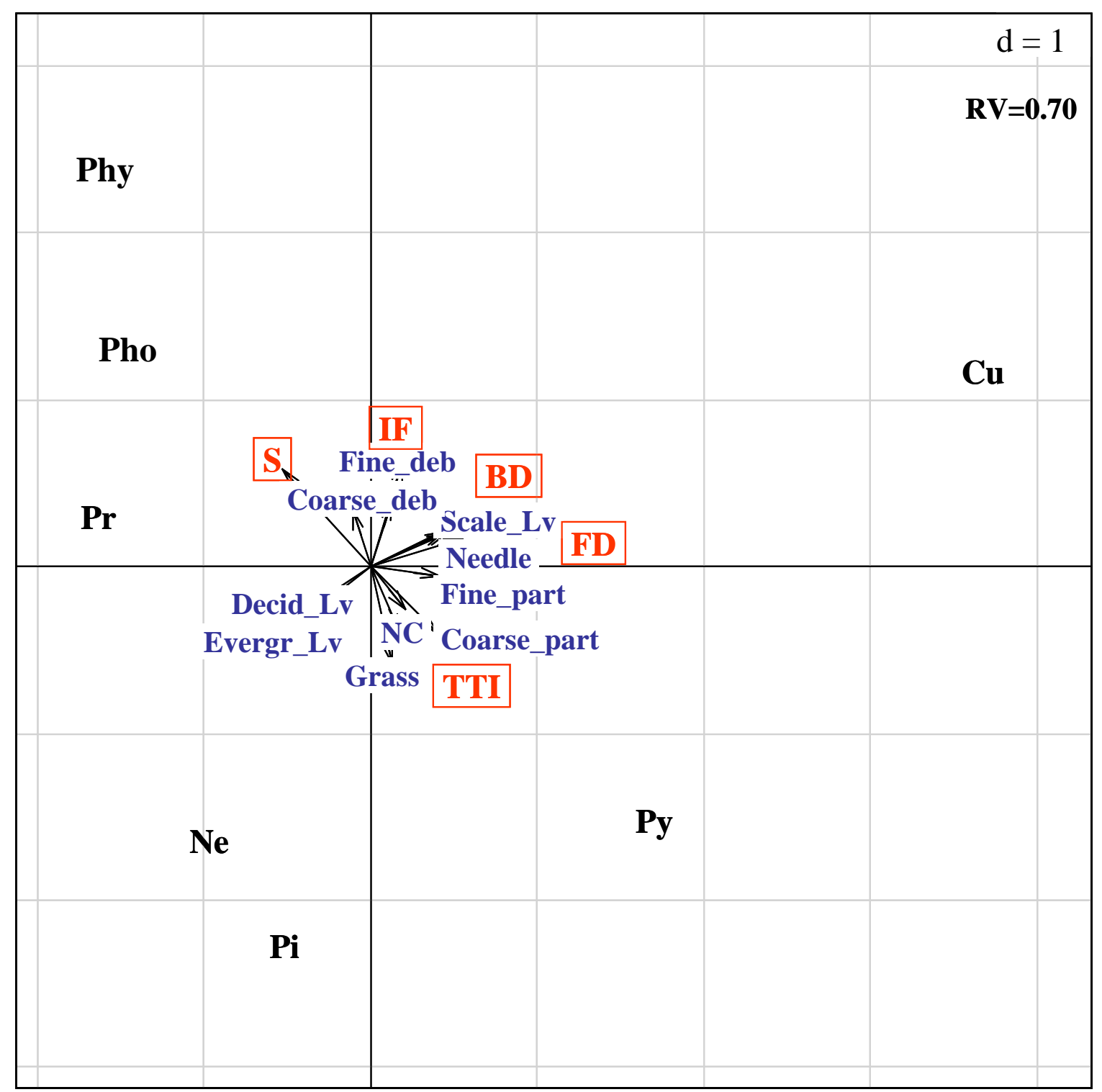

Fig. 6: Results of the co-inertia analysis performed on 10 classes of litter components (Decid_Lv: deciduous leaves, Evergr_Lv: evergreen leaves, NC: non-combustible particles, Coarse_part: coarse particles, Fine_part: fine particles, Scale_Lv: scale-like leaves, Fine_deb: fine debris, Coarse_deb: coarse debris) as explanatory variables and on 4 flammability parameters (TTI: time-to-ignition, FD: flaming duration, S: flame spread, IF: ignition frequency) and 1 litter structure parameter (BD: litter bulk-density) as dependent variables giving the position of species (Phy: Phyllostachys sp., Cu: Cupressus sempervirens, Ne: Nerium oleander, Pho: Photinia fraseri, Pi: Pittosporum tobira, Pr: Prunus laurocerasus and Py: Pyracantha coccinea) on the co-inertia Factor 1 $\mathrm{x}$ Factor 2 plane (d: scale of the plot, RV: RV coefficient, ranging from 0 to 1, measures global similarity between datasets). 
Author produced version of the article published in International Journal of Wildland Fire, 2012, 22(3) 333-342 Original publication available at www.publish.csiro.au/nid/114.htm doi:10.171/WF12006

Hierarchical cluster analysis, performed only on the flammability variables, ranked the relative flammability of the seven species in four clusters (Fig. 7): (i) P. tobira was rated as poorly flammable, (ii) N.oleander and Phyllostachys sp. as flammable, (iii) C. sempervirens and P. coccinea as moderately flammable and (iv) $P$. laurocerasus and $P$. fraseri as highly flammable.

\title{
Cluster Dendrogram
}

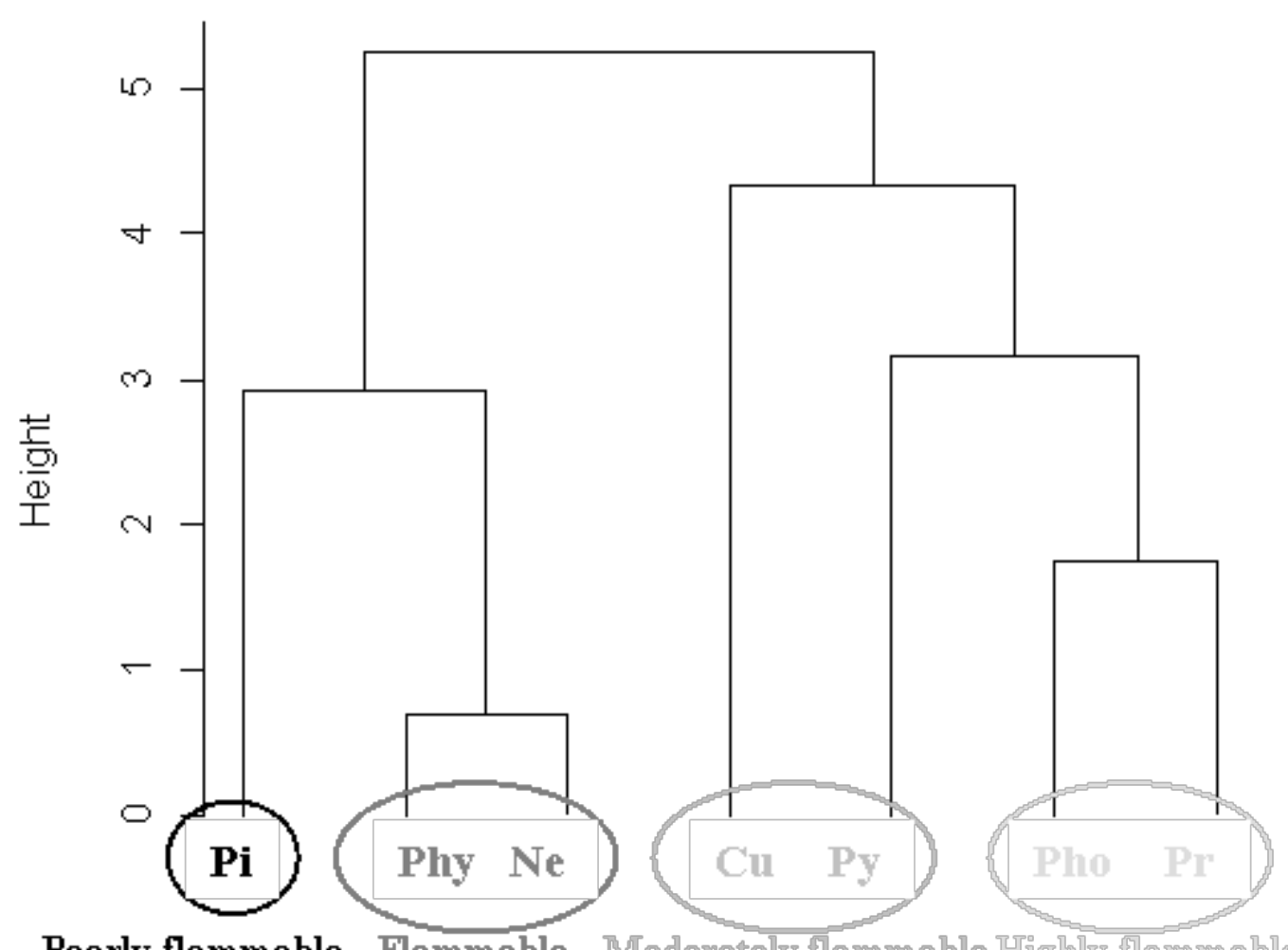

Poorly flammable Flammable Moderately flammable flighly flammable

\author{
dc \\ holust (", "ward")
}

Fig. 7: Hierarchical cluster analysis based on the flammability parameters (time-to-ignition, flaming duration, flame spread and ignition frequency) recorded during the burning of the litter of the seven species studied (Pi: Pittosporum tobira, Phy: Phyllostachys sp., Ne: Nerium oleander, Cu: Cupressus sempervirens, Py: Pyracantha coccinea, Pho: Photinia fraseri, Pr: Prunus laurocerasus). 
Author produced version of the article published in International Journal of Wildland Fire, 2012, 22(3) 333-342

Original publication available at www.publish.csiro.au/nid/114.htm

doi:10.171/WF12006

\section{Discussion}

\section{Composition of litters}

The sorting of the undisturbed litters sampled in monospecific hedges allowed us to determine their composition because the proportions of their components were assumed to have an influence on litter flammability (Ganteaume et al. 2011a; Curt et al. 2011). As the samples were not reconstructed, they were composed of different particles of different sizes, mainly taken from the two top soil layers (L and F) but a small proportion also came from the H layer (debris). Small proportions of components originating from other nearby species were present but these proportions did not vary between the different types of litter. Regarding the main components, the amount of evergreen leaves was the highest in $N$. oleander and P. laurocerasus litters (as these species have large leaves), and the highest amounts of scale-like leaves and coarse particles were found in C. sempervirens litter, the only species to have such foliage; it also had the largest fruits. Pyracantha coccinea litter had the largest amount of fine particles, as this thorny species has a lot of fine twigs and thorns. The largest amount of debris (regardless of their size) was found in Phyllostachys sp. litter, as this species has very thin leaves which slowly deteriorated, producing many leaf fragments of varying size. The fuel size affects the amount of potential fuel that can combust during a fire, fine fuel being more flammable than coarse fuel (Bond and Van Wilgen 1996; Baeza et al. 2002).

\section{Assessment of the flammability of heterogeneous dead fuels}

The litters of each species presented their own flammability mainly depending on their composition and bulk density because this variable, which determines fuel compaction in space, controls the rate of oxygen that can flow through the fuels as well as the heat transfer between fuel particles (Scarff and Westoby 2006). The moisture content of the oven-dried litter samples was assumed to not affect the flammability as it was very low.

Cupressus sempervirens litter had the highest bulk density values and low flame spread values but high flaming duration and ignition frequency values. This last result contrasts with those obtained in several studies in which an increase in fuel bulk density was shown to reduce potential fire behaviour, especially ignition success (Jerman et al. 2004; Glitzenstein et al. 2006; Plucinski and Anderson 2008). Nerium oleander and Phyllostachys sp. litters were quicker to ignite than was $P$. coccinea litter. However, $N$. oleander and P. tobira litters were the most difficult to ignite and to sustain flames. Prunus laurocerasus and $P$. fraseri litters had high flame spread values; in a general way, the litters of species with the largest leaves ( $P$. laurocerasus and $N$. oleander) had the highest values for flame spread but not for flaming duration. Scarff and Westoby (2006) reported that large leaves created an open litter bed structure which burned more rapidly because it was better ventilated. Leaf size was shown to be the most important trait influencing both the intensity and sustainability of litter fires, more than chemical factors known to influence flammability, such as oils and lignin content (Vines 1981; Parker and LeVan 1989). 
Author produced version of the article published in International Journal of Wildland Fire, 2012, 22(3) 333-342

Original publication available at www.publish.csiro.au/nid/114.htm

doi:10.171/WF12006

\section{Classification of species}

Results of the co-inertia analysis (Fig. 6) showed that bulk density was an important factor as was flaming duration, and both depended on the compaction of the litter (Scarff and Westoby 2006; Ormeño et al. 2009). The high proportion of coarse particles appeared to increase the time-to-ignition of litters, fine particles igniting more readily than coarse ones (Scarff and Westoby 2006), whereas the high proportion of scale-like leaves increased flaming duration and bulk density in the same way as pine needles increased flaming duration (Ganteaume et al. 2011a). Flame spread and ignition frequency appeared to be increased by high proportions of fine and coarse debris and decreased by high proportions of non-combustible and coarse particles, as reported previously by Ganteaume et al. (2011a).

Hierarchical cluster analysis (Fig. 7) grouped the species in four clusters based on their flammability, from the less flammable to the most flammable species. The ranking of species in four clusters was explained by the values for variables that indicated high or moderate flammability (Table 3). The poorly flammable species $P$. tobira had flaming duration significantly shorter than that of others species (Fig. 5) and low ignition frequency (Fig. 6), for instance. The cluster of flammable species (N. oleander and Phyllostachys sp.) had times-to-ignition significantly shorter than those of the other species (Fig. 5) and high ignition frequency (Fig. 6), which indicated high flammability. This result is consistent with those of Long et al. (2006b) who classified P. tobira in the cluster of species with low flammability (species recommended for planting in the WUI). However, several authors (Lubin and Shelly 1997; Etlinger and Beall 2004; Long et al. 2006b), using a different method to assess the flammability of species, classified $N$. oleander as poorly flammable whereas the results of our hierarchical analysis showed that this species belongs to the cluster of flammable species, along with Phyllostachys sp. The cluster of moderately flammable species (P. coccinea and C. sempervirens) presented high ignition frequency and long flaming duration, which indicated high flammability. In their study, Long et al. (2006b) also classified Leyland Cypress (Cupressocyparis leylandii), a species with the same structure as C. sempervirens, in the cluster of moderate flammable species but classified $P$. coccinea in the cluster of poorly flammable species. Our cluster of highly flammable species ( $P$. fraseri and $P$. laurocerasus) had either (i) high ignition frequency and flame spread (Fig. 6) as well as long flaming duration (for $P$. fraseri) which indicated high flammability, or (ii) high ignition frequency and flame spread (Fig. 6) which indicated high flammability as well as moderate flaming duration; this latter variable indicated moderate flammability (for $P$. laurocerasus). In the case of litter beds, large leaves like those of $P$. laurocerasus may increase flammability by reducing overall packing of fuels, hence increasing airflow (Scarff and Westoby 2006).

As the aim of this work was to assess the litter flammability of ornamental species regarding mainly ignitability and initial flame propagation, variables such as mass loss rate, flame height and temperature or peak heat release rate, which is very often measured especially for live leaf samples 
(White et al. 1997; Etlinger and Beall 2004; Weise et al. 2005; Long et al. 2006a) were not recorded during our burning experiments. Adding additional flammability variables to the analyses could change the ranking of species, especially for species that displayed an intermediate flammability. It is quite unlikely that a species like P. tobira, for which all variables indicated a very low flammability, would be ranked differently using other flammability measures.

\section{Conclusions}

The assessment of the litter flammability of the seven species enabled them to be ranked in four clusters according to their flammability. Pittosporum tobira showed very low flammability whereas $P$. fraseri and $P$. laurocerasus were ranked as highly flammable species. Nerium oleander and Phyllostachys sp. showed low flammability whereas P. coccinea and C. sempervirens were ranked as moderately flammable. The final ranking of species' flammability should take into account the results obtained in the study of flammability at particle level. In a future paper, the flammability of ornamental fuels at particle level will be assessed taking into account the proportions of the different particles, especially very fine fuel. The species with highly flammable characteristics at particle and surface fuel levels should not be used in hedges planted in the WUI in south-eastern France.

Fire behaviour in field situations is a product of the environment where the fire occurs (Pyne et al. 1996), so the results obtained in laboratory tests cannot be used directly to describe or predict the flammability of fuels in natural or real conditions. However, this type of data provides basic information that is very useful for assessing the fuel hazard of Mediterranean ornamental vegetation planted in hedges even if protocols to establish flammability need to be standardised to convert results into a classification that can be used widely (Weise et al. 2005; White and Zipperer 2010).

\section{Acknowledgements}

The authors thank the Cemagref technical staff: Roland Estève, Aminata N'Diaye, Marie Cabaret-Lampin, Florent Dalverny and Alice Lebeaux. This study was funded by the French Ministry of Ecology (service des risques naturels et hydroliques) and the direction générale de la prévention des risques (DGPR).

\section{References}

Anderson HE (1970) Forest fuel ignitability. Fire Technology 6, 312-319. doi:10.1007/BF02588932

Babrauska V (2003) ‘Ignition Handbook.’ (Fire science publishers: Issaquah, WA)

Babrauskas V (2002) Heat release rates. In ‘The SFPE Handbook of Fire Protection and Engineering’, 3rd edn. pp. 3-1-3-37. (National Fire Protection Association: Quincy, MA)

Baeza MJ, De Luis M, Raventos J, Escarre A (2002) Factors influencing fire behaviour in shrublands of different stand ages and the implications for using prescribed burning to reduce wildfire risk. Journal of Environmental Management 65, 199-208. doi:10.1006/jema.2002.0545 
Author produced version of the article published in International Journal of Wildland Fire, 2012, 22(3) 333-342

Original publication available at www.publish.csiro.au/nid/114.htm

doi:10.171/WF12006

Behm AL, Duryea ML, Long AJ, Zipperer WC (2004) Flammability of native understory species in pine flatwood and hardwood hammock ecosystems and implications for the wildland-urban interface. International Journal of Wildland Fire 13, 355-365. doi:10.1071/WF03075

Bond WJ, Van Wilgen BW (1996) 'Fire and Plants.’ (Chapman and Hall: London, UK).

Bradstock RA, Cohn JS (2002) Fire regimes and biodiversity in semi-arid mallee ecosystems. In 'Flammable Australia: the Fire Regimes and Biodiversity of a Continent’. (Eds RA Bradstock, JE Williams, AM Gill) pp. 238-258. (Cambridge University Press: Cambridge, UK)

Chuvieco E, Aguado I, Dimitrakopoulos AP (2004) Conversion of fuel moisture content values to ignition potential for integrated fire danger assessment. Canadian Journal of Forest Research 34, 2284-2293. $\underline{\text { doi:10.1139/x04-101 }}$

Curt T, Schaffhauser A, Borgniet L, Dumas C, Estève R, Ganteaume A, Jappiot M, Martin W, N'Diaye A, Poilvet B (2011) Litter flammability in oak woodlands and shrublands of southeastern France. Forest Ecology and Management 261, 2214-2222. doi:10.1016/j.foreco.2010.12.002

de la Riva J, Perez-Cabello F (2005) El factor humano en el riesgo de incendios forestales a escala municipal. Aplicación de técnicas SIG para su modelización. In 'La ciencia forestal: respuestas para la sostenibilidad’. 4 Congreso Forestal Español. Sociedad Española de Ciencias Forestales, Madrid.

de la Riva J, Perez-Cabello F, Chuvieco E (2006) Wildland fire ignition danger spatial modelling using GIS and satellite data. In EGU General Assembly - European Geosciences Union. Geophysical Research Abstracts 8, 10321.

Delabraze P, Valette J-C (1974) Inflammabilité et combustibilité de la végétation forestière méditerranéenne. Revue Forestière Française Numéro spécial, 171-177.

Dimitrakopoulos AP (2001) A statistical classification of Mediterranean species based on their flammability components. International Journal of Wildland Fire 10, 113-118. doi:10.1071/WF01004

Dimitrakopoulos AP, Panov PI (2001) Pyric properties of some dominant Mediterranean vegetation species. International Journal of Wildland Fire 10, 23-27. doi:10.1071/WF01003

Dimitrakopoulos AP, Papaioannou KK (2001) Flammability assessment of Mediterranean forest fuels. Fire Technology 37, 143-152. doi:10.1023/A:1011641601076

Dolédec S, Chessel D (1994) Co-inertia analysis; an alternative method for studying species-environment relationships. Freshwater Biology 31, 277-294. doi:10.1111/j.1365-2427.1994.tb01741.x

Etlinger MG, Beall FC (2004) Development of a laboratory protocol for fire performance of landscape plants. International Journal of Wildland Fire 13, 479-488. doi:10.1071/WF04039

Frandsen W (1997) Ignition probability of organic soils. Canadian Journal of Forest Research 27, 1471-1477. doi:10.1139/x97-106

Ganteaume A, Lampin C, Guijarro M, Hernando C, Jappiot M, Fonturbel T, Perez-Gorostiaga P, Vega JA (2009) Spot fires: fuel bed flammability and capability of firebrands to ignite fuel beds. International Journal of Wildland Fire 18, 951-969. doi:10.1071/WF07111 
Author produced version of the article published in International Journal of Wildland Fire, 2012, 22(3) 333-342

Original publication available at www.publish.csiro.au/nid/114.htm

doi:10.171/WF12006

Ganteaume A, Jappiot M, Lampin-Maillet C, Curt T, Borgniet L (2011a) Effects of vegetation type and fire regime on flammability of undisturbed litters in South-Eastern France. Forest Ecology and Management 261, 2223-2231. doi:10.1016/j.foreco.2010.09.046

Ganteaume A, Guijarro M, Jappiot M, Hernando C, Lampin-Maillet C, Perez-Gorostiaga P, Vega JA (2011b) Laboratory characterization of firebrands involved in spot fires. Annals of Forest Science 68(3), 531-541 doi:10.1007/s13595-011-0056-4.

Glitzenstein JL, Streng DR, Achtmeier GL, Naeher LP, Wade DD (2006) Fuels and fire behavior in chipped and unchipped plots: implications for land management near the wildland/urban interface. Forest Ecology and Management 236, 18-29 doi:10.1016/j.foreco.2006.06.002.

Jappiot M, Lampin C, Curt T, Ganteaume A, Borgniet L, Bouillon Ch, Chandioux O, Estève R, Long M, Martin W, Morge D, Alexandrian D, D’Avezac H, Tatoni T, Dumas E, Valette J-C, Moro C (2007) Modélisation et cartographie de l'aléa d'éclosion d'incendie de forêt. Programme AIOLI. Convention DGFAR 61.45.80.31/04 1. Convention DPFM du 06 décembre 2005. Rapport final.

Jerman JL, Gould PJ, Fulé PZ (2004) Slash compression treatment reduced tree mortality from prescribed fire in south-western ponderosa pine. Western Journal of Applied Forestry 19, 149-153.

Lawson B, Armitage B, Dalrymple GN (1996) Wildfire Ignition Probability Predictor (WIPP). Canadian Forest Service, Pacific Forestry Center, R\&D Update. (Victoria, BC)

Leone V, Koutsias N, Martínez J, Vega-García C, Allgöwer B, Lovreglio R (2003) The human factor in fire danger assessment. In 'Wildland Fire Danger Estimation and Mapping: the Role of Remote Sensing Data' (Ed. E. Chuvieco) pp. 143-196. (World Sci.: Hackensack, NJ)

Long AJ, Behm A, Zipperer WC, Hermansen A, Maranghides A, Mell W (2006a) Quantifying and ranking the flammability of ornamental shrubs in the southern United States. In '2006 Fire Ecology and Management Congress Proceedings’, 13-17 November 2006, San Diego, CA. (DVD) (The Association for Fire Ecology and Washington State University Extension: San Diego, CA)

Long A, Hinton B, Zipperer W, Hermansen-Baez A, Maranghides A, Mell W (2006b) Fire spread and structural ignitions from horticultural plantings in the wildland-urban interface. In 'Fire Ecology and Management Congress Proceedings', 13-17 November 2006, San Diego, CA. (DVD) (The Association for Fire Ecology and Washington State University Extension: San Diego, CA)

Lubin DM, Shelly JR (1997) Defensible space landscaping in the urban/wildland interface: a compilation of fire performance ratings of residential landscape plants. University of California, Forest Products Laboratory, Internal Report Number 36.01.137. (Richmond, CA)

Manzello SL, Cleary TG, Shields JR, Yang JC (2006a) On the ignition of fuel beds by firebrands. Fire and Materials 30, 77-87 doi:10.1002/fam.901.

Manzello SL, Cleary TG, Shields JR, Yang JC (2006b) Ignition of mulch and grasses by firebrands in wildlandurban interface fires. International Journal of Wildland Fire 15, 427-431 doi:10.1071/WF06031. 
Author produced version of the article published in International Journal of Wildland Fire, 2012, 22(3) 333-342

Original publication available at www.publish.csiro.au/nid/114.htm

doi:10.171/WF12006

Manzello SL, Maranghides A, Mell WE (2007) Firebrand generation from burning vegetation. International Journal of Wildland Fire 16, 458-462 doi:10.1071/WF06079.

Manzello SL, Cleary TG, Shields JR, Maranghides A, Mell W, Yang JC (2008) Experimental investigations of firebrands: generation and ignition of fuel beds. Fire Safety Journal 43, 226-233. doi:10.1016/j.firesaf.2006.06.010.

Manzello SL, Park SH, Cleary TG (2009) Investigation on the ability of glowing firebrands deposited within crevices to ignite common building materials. Fire Safety Journal 44, 894-900. doi:10.1016/j.firesaf.2009.05.001.

Martin RE, Gordon DA, Gutierrez ME, Lee DS, Molina DM, Schroeder RA, Sapsis DB, Stephens SL, Chambers M (1994) Assessing the flammability of domestic and wildland vegetation. In 'Proceedings of the 12th Conference on Fire and Forest Meteorology’, 26-28 October 1993, Jekyll Island, GA. pp. 130-137 (Society of American Foresters: Bethesda, MD).

Monroe MC, Long AJ, Marynowski S (2003) Wildland fire in the Southeast: negotiating guidelines for defensible space. Journal of Forestry 101, 14-19.

Moretti M, Legg C (2009) Combining plant and animal traits to assess community functional responses to disturbance. Ecography 32, 299-309. doi:10.1111/j.1600-0587.2008.05524.x

Ormeño E, Céspedes B, Sánchez IA, Velasco-García A, Moreno J, Fernandez C, Baldy V (2009) The relationship between terpenes and flammability of leaf litter. Forest Ecology and Management 257, 471-482. doi:10.1016/j.foreco.2008.09.019

Parker WJ, LeVan SL (1989) Kinetic properties of the components of Douglas-fir and the heat of combustion of their volatile pyrolysis products. Wood and Fiber Science 21, 289-305.

Pellizzaro G, Duce P, Ventura A, Zara P (2007) Seasonal variations of live moisture content and ignitability in shrubs of the Mediterranean Basin. International Journal of Wildland Fire 16, 633-641. doi:10.1071/WF05088

Petriccione M, Moro C, Rutigliano FA (2006) Preliminary studies on litter flammability in Mediterranean region. Forest Ecology and Management •••, 234S.

Plucinski MP, Anderson WR (2008) Laboratory determination of factors influencing successful point ignition in the litter layer of shrubland vegetation. International Journal of Wildland Fire 17, 628-637. doi:10.1071/WF07046

Pyne SJ, Andrews PL, Laven RD (1996) ‘Introduction to Wildland Fire’, 2nd edn. (Wiley: New York).

R Development Core Team (2005) R: A Language and Environment for Statistical Computing, Reference Index Version v. 2.5.1. (R Foundation for Statistical Computing: Vienna, Austria).

Scarff FR, Westoby M (2006) Leaf litter flammability in some semi-arid Australian woodlands. Functional Ecology 20, 745-752. doi:10.1111/j.1365-2435.2006.01174.x

ter Braak CJF, Schaffers AP (2004) Co-correspondence analysis: a new ordination method to relate two community compositions. Ecology 85, 834-846. doi:10.1890/03-0021 
Author produced version of the article published in International Journal of Wildland Fire, 2012, 22(3) 333-342

Original publication available at www.publish.csiro.au/nid/114.htm

doi:10.171/WF12006

Thioulouse J, Chessel D, Doledec S, Olivier JM (1997) ADE-4: a multivariate analysis and graphical display software. Statistics and Computing 7, 75-83. doi:10.1023/A:1018513530268

Valette JC (1990) Flammability of Mediterranean forest species. Effects on the combustibility of vegetation types. Revue Forestière Française, 76-92.

Vines RG (1981) Physics and chemistry of rural fires. In 'Fire and the Australian Biota’ (Eds RM Gill, RH Groves, IR Noble) pp. 129-149. (Australian Academy of Science: Canberra)

Weise DR, White RH, Beall FC, Etlinger M (2005) Use of the cone calorimeter to detect seasonal differences in selected combustion characteristics of ornamental vegetation. International Journal of Wildland Fire 14, 321338 doi:10.1071/WF04035.

White RH, Zipperer WC (2010) Testing and classification of individual plants for fire behaviour: plant selection for the wildland-urban interface. International Journal of Wildland Fire 19, 213-227. doi:10.1071/WF07128

White RH, DeMars D, Bishop M (1997) Flammability of Christmas trees and other vegetation. In 'Proceedings of the 24th international conference on fire safety’, 21-24 July 1997, Columbus, OH. (Ed. CJ Hilado) pp. 99110 (Products Safety Corporation: Sissonville, WV). 
Author produced version of the article published in International Journal of Wildland Fire, 2012, 22(3) 333-342

Original publication avalable at www publish csiro au/nid/114. htm

doi:10.171/WF12006

Table 1. Proportions of each litter component after sorting of the litter sub-samples of each species studied

Mean (standard deviation) and $n$ are the number of litter sub-samples in which the component was identified by the total number of samples sorted for each

species

\begin{tabular}{|c|c|c|c|c|c|c|c|c|c|c|c|c|c|c|c|c|c|c|c|c|}
\hline \multirow[b]{2}{*}{ Species } & \multicolumn{2}{|c|}{$\begin{array}{l}\text { Deciduous } \\
\text { leaves }\end{array}$} & \multicolumn{2}{|c|}{$\begin{array}{l}\text { Evergreen } \\
\text { leaves }\end{array}$} & \multicolumn{2}{|c|}{$\begin{array}{c}\text { Scale-like } \\
\text { leaves }\end{array}$} & \multicolumn{2}{|c|}{ Needles } & \multicolumn{2}{|c|}{ Grass } & \multicolumn{2}{|c|}{ Fine particles } & \multicolumn{2}{|c|}{$\begin{array}{c}\text { Coarse } \\
\text { particles }\end{array}$} & \multicolumn{2}{|c|}{ Fine debris } & \multicolumn{2}{|c|}{$\begin{array}{l}\text { Coarse } \\
\text { debris }\end{array}$} & \multicolumn{2}{|c|}{ Non-combustible } \\
\hline & $n$ & Mean (s.d.) & $n$ & Mean (s.d.) & $n$ & $\begin{array}{l}\text { Mean } \\
\text { (s.d.) }\end{array}$ & $n$ & $\begin{array}{l}\text { Mean } \\
\text { (s.d.) }\end{array}$ & $n$ & $\begin{array}{l}\text { Mean } \\
\text { (s.d.) }\end{array}$ & $n$ & $\begin{array}{l}\text { Mean } \\
\text { (s.d.) }\end{array}$ & $n$ & $\begin{array}{l}\text { Mean } \\
\text { (s.d.) }\end{array}$ & $n$ & $\begin{array}{l}\text { Mean } \\
\text { (s.d.) }\end{array}$ & $n$ & $\begin{array}{l}\text { Mean } \\
\text { (s.d.) }\end{array}$ & $n$ & Mean (s.d.) \\
\hline $\begin{array}{l}\text { Phyllostachys } \\
\text { sp. }\end{array}$ & $4 / 4$ & $5.36(2.52)$ & $4 / 4$ & $\begin{array}{c}8.12 \\
(3.52)\end{array}$ & $0 / 4$ & 0 & $0 / 4$ & 0 & $0 / 4$ & 0 & $4 / 4$ & $\begin{array}{c}3.01 \\
(0.57)\end{array}$ & $4 / 4$ & $\begin{array}{c}4.18 \\
(0.92)\end{array}$ & $4 / 4$ & $\begin{array}{l}32.82 \\
(5.36)\end{array}$ & $4 / 4$ & $\begin{array}{l}43.00 \\
(4.40)\end{array}$ & $4 / 4$ & $3.51(3.10)$ \\
\hline $\begin{array}{l}\text { Cupressus } \\
\text { sempervirens }\end{array}$ & $6 / 7$ & $1.05(0.78)$ & $7 / 7$ & $\begin{array}{c}0.01 \\
(0.02)\end{array}$ & $7 / 7$ & $\begin{array}{c}20.73 \\
(17.23)\end{array}$ & $3 / 7$ & $\begin{array}{c}7.50 \\
(12.61)\end{array}$ & $3 / 7$ & $\begin{array}{c}0.22 \\
(0.36)\end{array}$ & $6 / 7$ & $\begin{array}{c}6.84 \\
(4.18)\end{array}$ & $7 / 7$ & $\begin{array}{l}21.94 \\
(9.67)\end{array}$ & $7 / 7$ & $\begin{array}{c}22.31 \\
(15.65)\end{array}$ & $7 / 7$ & $\begin{array}{c}9.51 \\
(8.85)\end{array}$ & $7 / 7$ & $9.90(12.78)$ \\
\hline $\begin{array}{l}\text { Nerium } \\
\text { oleander }\end{array}$ & $3 / 6$ & 1.98 (3.91) & $6 / 6$ & $\begin{array}{c}69.64 \\
(17.02)\end{array}$ & $0 / 6$ & 0 & $0 / 6$ & 0 & $3 / 6$ & $\begin{array}{c}0.58 \\
(0.76)\end{array}$ & $6 / 6$ & $\begin{array}{c}4.54 \\
(2.06)\end{array}$ & $5 / 6$ & $\begin{array}{c}6.55 \\
(4.36)\end{array}$ & $6 / 6$ & $\begin{array}{c}0.41 \\
(0.57)\end{array}$ & $6 / 6$ & $\begin{array}{l}1.69 \\
(2.88)\end{array}$ & $6 / 6$ & $\begin{array}{c}14.62 \\
(10.15)\end{array}$ \\
\hline $\begin{array}{l}\text { Photinia } \\
\text { fraseri }\end{array}$ & $0 / 4$ & 0 & $4 / 4$ & $\begin{array}{c}50.81 \\
(13.54)\end{array}$ & $0 / 4$ & 0 & $0 / 4$ & 0 & 4 & $\begin{array}{c}0.05 \\
(0.10)\end{array}$ & $4 / 4$ & $\begin{array}{c}4.60 \\
(1.13)\end{array}$ & $0 / 4$ & 0 & $4 / 4$ & $\begin{array}{l}15.25 \\
(5.40)\end{array}$ & $4 / 4$ & $\begin{array}{l}23.13 \\
(5.72)\end{array}$ & $4 / 4$ & $6.16(6.72)$ \\
\hline $\begin{array}{l}\text { Pittosporum } \\
\text { tobira }\end{array}$ & $3 / 8$ & $2.60(5.31)$ & $8 / 8$ & $\begin{array}{c}59.69 \\
(15.16)\end{array}$ & $0 / 8$ & 0 & $0 / 8$ & 0 & $5 / 8$ & $\begin{array}{c}0.94 \\
(1.18)\end{array}$ & $8 / 8$ & $\begin{array}{c}4.25 \\
(3.60)\end{array}$ & $8 / 8$ & $\begin{array}{c}18.92 \\
(11.84)\end{array}$ & $8 / 8$ & $\begin{array}{c}1.98 \\
(2.93)\end{array}$ & $8 / 8$ & $\begin{array}{c}2.73 \\
(3.21)\end{array}$ & $8 / 8$ & $8.90(15.04)$ \\
\hline $\begin{array}{l}\text { Prunus } \\
\text { laurocerasus }\end{array}$ & $3 / 5$ & $0.65(0.71)$ & $5 / 5$ & $\begin{array}{c}62.28 \\
(19.62)\end{array}$ & $0 / 5$ & 0 & $0 / 5$ & 0 & $1 / 5$ & $\begin{array}{c}0.04 \\
(1.18)\end{array}$ & $5 / 5$ & $\begin{array}{c}3.05 \\
(1.96)\end{array}$ & $3 / 5$ & $\begin{array}{c}3.59 \\
(5.80)\end{array}$ & $5 / 5$ & $\begin{array}{l}2.65 \\
(2.48)\end{array}$ & $5 / 5$ & $\begin{array}{c}18.20 \\
(14.19)\end{array}$ & $5 / 5$ & 9.55 (9.44) \\
\hline $\begin{array}{l}\text { Pyracantha } \\
\text { coccinea }\end{array}$ & $2 / 5$ & $0.32(0.49)$ & $5 / 5$ & $\begin{array}{l}21.04 \\
(6.13)\end{array}$ & $5 / 5$ & $\begin{array}{c}0.12 \\
(0.28)\end{array}$ & $1 / 5$ & $\begin{array}{c}0.46 \\
(1.04)\end{array}$ & $4 / 5$ & $\begin{array}{l}1.10 \\
(2.18)\end{array}$ & $5 / 5$ & $\begin{array}{l}10.02 \\
(6.05)\end{array}$ & $5 / 5$ & $\begin{array}{l}17.47 \\
(5.23)\end{array}$ & $5 / 5$ & $\begin{array}{l}12.36 \\
(9.52)\end{array}$ & $5 / 5$ & $\begin{array}{c}21.45 \\
(10.67)\end{array}$ & $5 / 5$ & $\begin{array}{c}15.72 \\
(13.22)\end{array}$ \\
\hline
\end{tabular}


Author produced version of the article published in International Journal of Wildland Fire, 2012, 22(3) 333-342

Original publication available at www.publish.csiro.au/nid/114.htm

doi:10.171/WF12006

Table 2. Flammability variables for the litter of each species studied and results of the statistical analyses

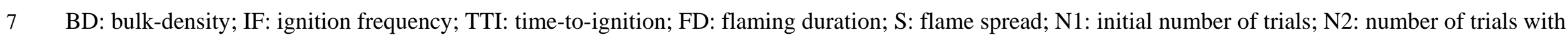
ignition, mean (standard deviation), time-to-ignition and flaming duration were log transformed; KW: Kruskal-Wallis test; F: Fisher test

\begin{tabular}{|c|c|c|c|c|c|c|c|c|}
\hline Species & Mass (kg) & $\mathrm{BD}\left(\mathrm{kg} \mathrm{m}^{-3}\right)$ & N1 & IF (\%) & N2 & TTI (s) & FD (s) & S (number of sides) \\
\hline Phyllostachys sp. & $0.067(0.01)$ & $34.6(5.4)$ & 31 & 68 & 21 & $56(33)$ & $66(33)$ & $3.4(0.5)$ \\
\hline Cupressus sempervirens & $0.169(0.03)$ & 243.1 (129.7) & 30 & 90 & 33 & $92(80)$ & 148 (107) & $2.4(1.3)$ \\
\hline Nerium oleander & $0.028(0.01)$ & 37.7 (13.2) & 30 & 57 & 19 & 49 (36) & $67(23)$ & $3.1(1.2)$ \\
\hline Photinia fraseri & $0.063(0.06)$ & 38.7 (13.5) & 30 & 100 & 30 & $97(60)$ & $108(34)$ & 4.0 \\
\hline Pittosporum tobira & $0.026(0.02)$ & $42.1(26.4)$ & 30 & 20 & 13 & 117 (114) & $55(46)$ & $2.5(1.7)$ \\
\hline Prunus laurocerasus & $0.044(0.02)$ & $27.5(9.7)$ & 30 & 83 & 36 & 153 (109) & 75 (37) & $3.5(0.7)$ \\
\hline Pyracantha coccinea & $0.077(0.03)$ & 49.3 (19.7) & 30 & 93 & 31 & $188(132)$ & $145(82)$ & $2.6(1.0)$ \\
\hline Statistical tests & & $\begin{array}{c}\mathrm{KW}=16.85, P= \\
0.0098\end{array}$ & & $\begin{array}{c}\mathrm{KW}=70.30, P< \\
0.0001\end{array}$ & & $F=9.92, P<0.0001$ & $F=9.58, P<0.0001$ & $\begin{array}{c}\mathrm{KW}=56.31, P< \\
0.0001\end{array}$ \\
\hline
\end{tabular}


Author produced version of the article published in International Journal of Wildland Fire, 2012, 22(3) 333-342

Original publication available at www.publish.csiro.au/nid/114.htm

doi:10.171/WF12006

\begin{tabular}{lcccc}
\hline Variables & Poorly flammable & Flammable & Moderately flammable & Highly flammable \\
\hline Time-to-ignition (s) & $>90$ & $<60$ & $>90$ & $>90$ \\
Ignition frequency (\%) & $<30$ & $50-70$ & $>80$ & $>80$ \\
Flaming duration (s) & $<50$ & $60-70$ & $>140$ & $75-110$ \\
Flame spread (N) & $<2.6$ & $3-3.5$ & $<2.6$ & $\geq 3.5$ \\
\hline
\end{tabular}

Fig. 1. Map of the study area (Département des Bouches du Rhône) in south-eastern France showing where the hedges were surveyed (BD Carto). White spots, coastal area; black spots, inland area.

Fig. 2. Sampling of undisturbed cypress litter.

Fig. 3. The burning device used for the flammability experiments ( $a$ ) and a top view of a burned sample showing the results of the flame spread (b). Domestic fan provides a $9.8 \mathrm{kmh}^{-1}$ wind.

Fig. 4. Litter composition (percent of each component) of each species studied (Phyllost., Phyllostachys sp.; Dec_Lv, deciduous leaves; Evergr_Lv, evergreen leaves; scale_lv, scale-like leaves; N, needles; Gr, grass; fine_part, fine particles; coarse_part, coarse particles; NC, non-combustible; fine_deb, fine debris; coarse_deb, coarse debris). For each bar, different letters indicate a statistically significant difference among species according to the one-way ANOVA. Where no letters are indicated, no differences among species were detected (proportions of each component were log transformed).

Fig. 5. Variation in (a) time-to-ignition (TTI), $(b)$ flaming duration (FD) and (c) flame spread (number of sides reached by the flames) of the litter samples for each species (Phy, Phyllostachys sp.; Cu, Cupressus sempervirens; Ne, Nerium oleander; Pho, Photinia fraseri; Pi, Pittosporum tobira; Pr, Prunus laurocerasus; Py, Pyracantha coccinea). One-way ANOVAs, box extends from lower quartile to upper quartile covering 50\% of the data values. Horizontal line within the box shows the location of the sample median and + shows the location of the sample mean. Whiskers extend from the quartile to the largest or smallest value in the sample. Notch covers an approximate confidence interval for the population median (confidence level =95\%).

Fig. 6. Results of the co-inertia analysis performed on 10 classes of litter components (Decid_Lv, deciduous leaves; Evergr_Lv, evergreen leaves; NC, non-combustible particles; Coarse_part, coarse particles; Fine_part, fine particles; Scale_Lv, scale-like leaves; Fine_deb, fine debris; Coarse_deb, coarse debris) as explanatory variables and on four flammability parameters (TTI, time-to-ignition; FD, flaming duration; S, flame spread; IF, ignition frequency) and one litter structure parameter (BD, litter bulk-density) as dependent variables giving the position of species (Phy, Phyllostachys sp.; Cu, Cupressus sempervirens; Ne, Nerium oleander; Ph, Photinia fraseri; Pi, Pittosporum tobira; Pr, Prunus laurocerasus; Py, Pyracantha coccinea) on the co-inertia Factor $1 \times$ Factor 2 plane (d, scale of the plot; RV, RV coefficient, ranging from 0 to 1, measures global similarity between datasets).

Fig. 7. Hierarchical cluster analysis based on the flammability parameters recorded during the burning of the litter of the seven species studied (Pi, Pittosporum tobira; Phy, Phyllostachys sp.; Ne, Nerium oleander; Cu, Cupressus sempervirens; Py, Pyracantha coccinea; Ph, Photinia fraseri; Pr, Prunus laurocerasus). 